\title{
Integrated Use of Geological, Geophysical, Radiocarbon and Stable Isotopes Data for Tracing the Conduit Flow Paths in a Small Karstic Aquifer: Poocher Swamp Freshwater Lens, South Australia
}

\author{
Nara Somaratne ${ }^{1} \&$ Simon Mann ${ }^{2}$ \\ ${ }^{1}$ South Australian Water Corporation, 250 Victoria Square, Adelaide, SA 5000, Australia \\ ${ }^{2}$ Zonge Engineering \& Research Organization (Australia) Pty Ltd, 39 Raglan Avenue, Edwardstown, SA 5039, \\ Australia \\ Correspondence: Nara Somaratne, South Australian Water Corporation, 250 Victoria Square, Adelaide, SA 5000, \\ Australia. Tel: 618-7424-2379. E-mail: nara.somaratnef@sawater.com.au
}

Received: August 19, 2016

Accepted: September 19, 2016

Online Published: September 28, 2016

doi:10.5539/enrr.v6n3p119

URL: http://dx.doi.org/10.5539/enrr.v6n3p119

\begin{abstract}
An integrated approach combining lithological logs, downhole geophysics, electromagnetic survey and the distribution of radiocarbon $\left({ }^{14} \mathrm{C}\right)$ and the stable isotopes of water molecules $\left({ }^{18} \mathrm{O}\right)$ were used to identify the conduit flow paths of a small freshwater lens. Lost circulation zones, where drilling fluid flows into geological formation instead returning up the annulus recorded during water well drilling, were considered as the major fracture zones. The presence of high porosity zones within boreholes were identified using caliper, gamma and neutron logs. These methods were used to identify the depth intervals at which cavities and the existence of conduit porosity within the boreholes. Transient electromagnetic (TEM) method was used to investigate resistivity anomalies in the profiles along nine pre-determined lines across the freshwater lens. Resistivity anomalies were related to borehole information and other surface features such as sinkholes. Low resistivity zones of the TEM tomography sections had excellent correlation to fracture zones identified during well drilling, and downhole geophysical logs. Similarly, high resistivity zones in the profiles correlate well with the zones of cemented or recrystallized limestone identified from the lithological logs. The interpreted resistivity anomaly accurately depicts depth to watertable at $15-18 \mathrm{~m}$, presence of main fracture zone at 20-25 m, presence of possible conduits flow paths and the cemented or recrystallized limestone below $35 \mathrm{~m}$ depth. The ${ }^{14} \mathrm{C}$, ${ }^{13} \mathrm{C}$ and ${ }^{18} \mathrm{O}$ signatures of the groundwater confirm the presence of conduits and potential pathways of preferential flows. This investigation illustrates the effectiveness using an integrated approach to trace the conduit flow paths in karst aquifers. The information gained from the study is currently being used for the management of the freshwater lens.
\end{abstract}

Keywords: karst aquifer, groundwater, conduit flow, resistivity tomography, radiocarbon, stable isotopes

\section{Introduction}

When fresh water lenses are formed in association with high recharge in karstic aquifers, identification of conduit flow paths is critical for sustainable management of the resource. This is particularly important in arid and semi-arid countries as the demand for water is ever increasing for agriculture, industry and community water supplies (WWRD, 2015). Karst aquifers possess both diffuse and conduit flow and varying degrees of connectivity between surface and groundwater over spatial scales that results in complex hydrology (Edwards et al., 2013). The surface-groundwater connection and flow regime must be properly identified and characterized to improve management of karst aquifers. In most karst areas, the majority of groundwater is carried through a subsurface conduit system. Subsurface conduits often connect to land surface via sinkholes, and serve as major pathways for groundwater flow in karst aquifers. Locating conduit flow paths from the surface, however, is one of the most challenging tasks in karst research (Zhu et al., 2011). Exploitation of fresh water lenses that are formed due to point recharge from sinkholes is challenging. This involves identification of conduits pathways which serve groundwater flow in karst system (ibid). A number of direct and indirect techniques are used to identify conduit flows. Direct method of identifying conduit pathways is possible during drilling, as it is noticeable when intersecting a large cavity, but not so noticeable if intersecting a small conduit, unless core samples are collected 
(Somaratne, 2015a). However, downhole geophysical techniques such as caliper, gamma and neutron logs provide additional information on fracture zones in a borehole. Collection of stratigraphic information by drilling large number of boreholes is prohibitively expensive and not always successful in intercepting conduit porosity zones, hence requires alternative techniques to identify major flow paths.

Geophysical methods are often deployed to help locate voids by mapping variations of physical properties of the subsurface (Zhu et al. 2011), as the conduits can cause significant contrasts of some physical properties that can be detected. Electrical resistivity is one of the commonly used geophysical methods for subsurface void detection, as a water-filled underground void has lower resistivity than most surrounding rocks whereas an air filled void has higher resistivity than most geologic material (Zhu et al., 2011). Geophysical techniques allow large areas to be covered in a short period of time and represent an efficient way of detecting subsurface heterogeneities including voids (Farooq et al., 2012). This provides much more effective and economic way to reduce the overall amount of drillings and to improve locating test drilling for verification (Metwaly \& AlFouzan, 2013). The electrical resistivity method is based on assumption that various entities like minerals, solid bedrock, sediments, air and water filled structures have detectable electrical resistivity contrast relative to the host medium (Panek et al., 2010). The electromagnetic tomography involves determination of the subsurface distribution of electrical resistivity. The varying geoelectric response enables to obtain $2 \mathrm{D}$ profiles of the resistivity distribution underground to characterize possible discontinuities in the subsurface (Martinez-Lopez et al., 2013).

Geochemical and isotopic data have been used in numerous studies in different karst regions to characterize the flow in carbonate aquifers and degree of surface-groundwater connections (Edwards et al., 2013). Knierim et al. (2015) show that stable isotope analyses are valuable in karst settings. As groundwater flow in karst aquifers is shared between the granular porosity and karst conduits, an indirect way of identification of major flow paths are possible using salinity distributions (Somaratne, 2015a), tracer techniques such as radiocarbon activity $\left({ }^{14} \mathrm{C}\right)$ and stable isotope $\left(\delta^{18} \mathrm{O}\right)$ distribution (Somaratne et al., 2016). In a similar study, Einsiedl (2005) analyzed concentration breakthrough curves obtained from a tracer test and time series of environmental tracers to characterize slow and preferential flow in a karst aquifer. Tritium $\left({ }^{3} \mathrm{H}\right)$ and chemical tracers (bromide, strontium) have been used in this study. For tracing the young fraction of groundwater mixture, Plummert et al. (1998) used transient tracers and dissolved substances including: chloride, ${ }^{3} \mathrm{H}$, tritogenic helium-3, chlorofluorocarbons, organic carbon, $\delta^{18} \mathrm{O}$. Plummer et al.'s study revealed that concentrations have been affected by dilution and mixing; groundwater mixing fractions have been determined by using dissolved chloride and $\delta^{18} \mathrm{O}$. Groundwater chemistry has been used to distinguish groundwater flow paths in different fractured-rock aquifers by Tweed et al. (2005). In their study, differences in groundwater chemistry between aquifers and between shallow and deeper flow systems, highlights inter-aquifer mixing. Nativ et al. (1999) used radioactive and stable isotope to identify and separate groundwater flow components in a karstified aquifer, with the use of ${ }^{14} \mathrm{C}$ to identify mixing of recent and older waters.

Problems arise when attempting to trace conduit flowpaths using a single technique given limitations in the each resulting in large uncertainty. Therefore, in this study, we use an inter-disciplinary integrated approach to study distribution of conduit flow paths in a small fresh water lens in the south-east of South Australia. The study uses geological information obtained by well drilling, downhole geophysical logs, resistivity data from high resolution electromagnetic (EM) in conjunction with radiocarbon and stable isotope distribution within the fresh water lens.

\section{Study Site: Poocher Swamp Freshwater Lens}

The study site, Poocher Swamp fresh water lens, is located $275 \mathrm{~km}$ south-east from Adelaide (Figure 1) and is within the Tatiara catchment. The catchment area extends across the South Australian border into western Victoria and previously described by Somaratne (2014). For brevity, a succinct summary of the study freshwater lens is provided here. The Tatiara catchment area is approximately $500 \mathrm{~km}^{2}$ (Herczeg et al., 1997) and the Creek flows in a westerly direction through to Poocher Swamp and disappear via sinkholes. The catchment features average annual rainfall ranging from 400 to $500 \mathrm{~mm}$ and pan evaporation of $2000 \mathrm{~mm}$. The unconfined aquifer is Murray Group Limestone and contains brackish water with average total dissolved solids (TDS) $>1400 \mathrm{mg} \cdot \mathrm{L}^{-1}$. Freshwater with TDS $<1000 \mathrm{mg} \mathrm{L}^{-1}$ occurs at locations where point recharge takes place through sinkholes. The Poocher Swamp freshwater lens, which is the largest of these freshwater plumes that float on brackish water, is a result of flows from Tatiara Creek that enter Poocher Swamp. The major recharge is through two sinkholes located in the northwest section of the swamp (Herczeg et al., 1997). The area encompassed by the $1000 \mathrm{mg} . \mathrm{L}^{-1}$ salinity contour comprises approximately $9 \mathrm{~km}^{2}$ in 2016. Surface water flows in Tatiara Creek is highly irregular, with annual volumes of freshwater $(0.05-2) \times 10^{6} \mathrm{~m}^{3}$ per year, but on rare occasions up to $19 \times 10^{6} \mathrm{~m}^{3}$ per year (Figure 2). Groundwater flow direction of the lens is from east to west. The study area is a relatively flat terrain with ground 
elevations at WRG032 well near the Poocher Swamp (Figure 1) at 69.83 m AHD (Australian Height Datum) while the most down gradient well WRG046 is at $66.24 \mathrm{~m}$ AHD. Depth to water varies, about $19 \mathrm{~m}$ at WRG032 and 15.6 $\mathrm{m}$ at WRG 046, with overall average of the freshwater lens area about $17 \mathrm{~m}$. Currently, an annual volume of $0.6 \times 10^{6} \mathrm{~m}^{3}$ of groundwater is extracted from the freshwater lens for town water supply to Bordertown, approximately $7 \mathrm{~km}$ east from the lens.

The unconfined aquifer is part of the Murray Group Limestone aquifer, which comprises a consolidated, highly fossiliferous and fine to coarse bioclastic limestone. Saturated thickness of the limestone unconfined aquifer is approximately 50-60 m. During high flows in the Tatiara Creek, Poocher Swamp overflows through the outlet channel to Scowns sinkholes, about $4 \mathrm{~km}$ further west (Figure 1). Based on average annual flow data of Tatiara Creek near Bordertown for 1980-2010 periods, Somaratne (2014) suggested annual recharge to the lens through sinkholes at Poocher Swamp was about $2.5 \times 10^{6} \mathrm{~m}^{3}$, but could not be quantified with any reliable precision.

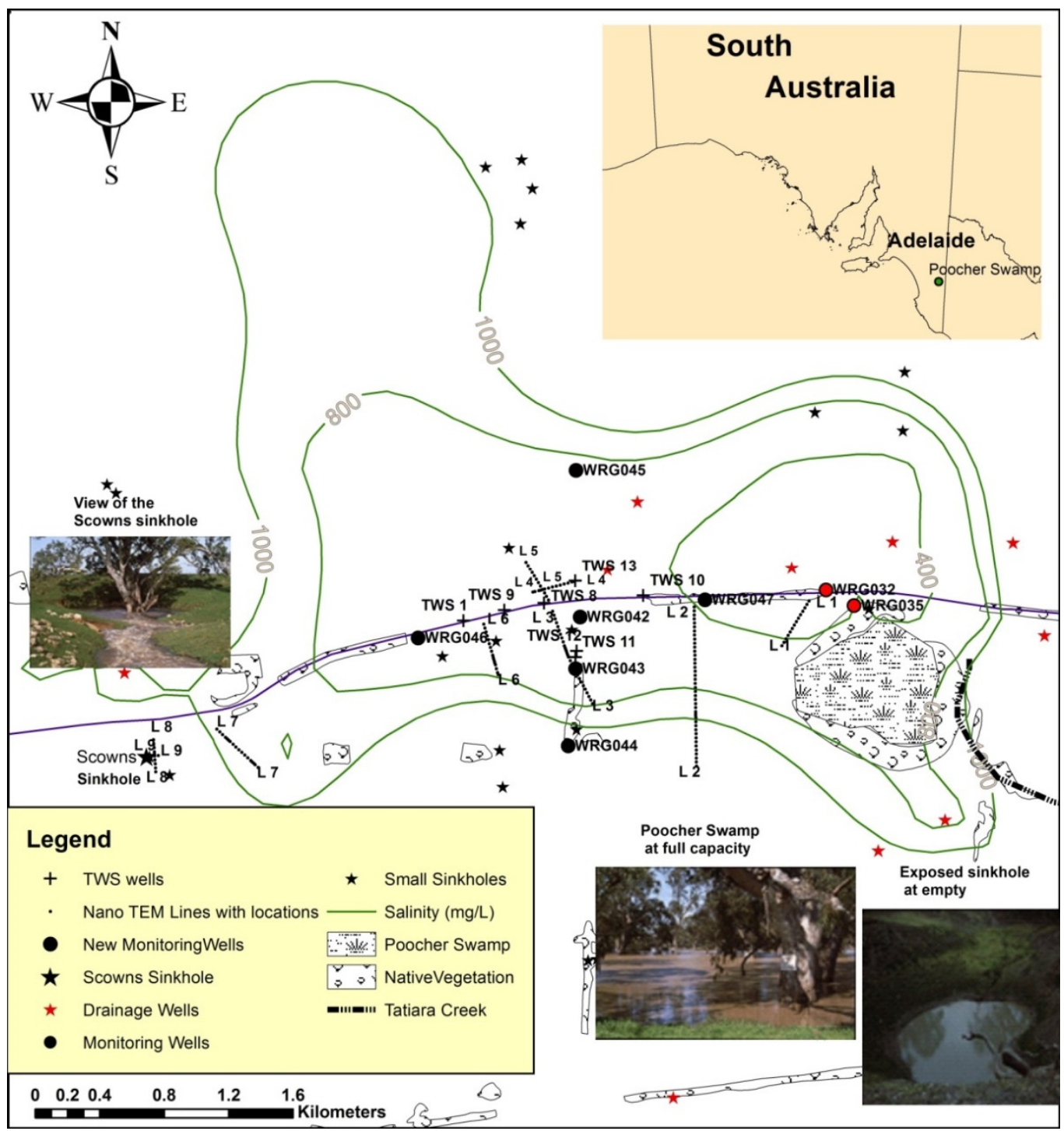

Figure 1. Poocher Swamp freshwater lens

In addition to town water supply, groundwater is also extracted within and from surrounding areas for irrigated agriculture, mainly for pasture, legumes and for viticulture. Dryland grazing is common within the lens area and the surroundings. As such, prudent management of the Poocher Swamp fresh water lens is vital for sustaining local economic activities. 


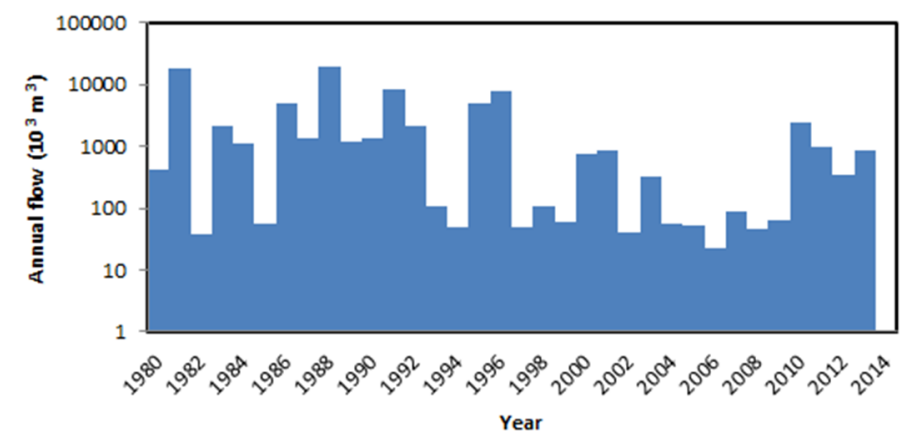

Figure 2. Annual flow of Tatiara Creek measured at Bordertown (in 2014 and 2015, flow measurements were not undertaken)

\section{Method}

Water samples were collected from Tatiara Creek, Poocher Swamp, monitoring wells and town water supply wells in 2012, 2014 and 2016. For monitoring wells, groundwater samples were collected using micro-purge (low-flow) sampling procedure (Vail, 2011) and for town water supply wells, samples were collected after allowing threebore volume discharge to ensure samples are representative of the aquifer water. Water samples were preserved according to the standard methods specified in the Australia/New Zealand standard, AS/NZS 5667.5 (1998) guidelines. Water samples for stable isotope analysis were collected in $30 \mathrm{~mL}$ McArtney glass bottles with metal screw top lids with rubber insert. In order to reduce evaporation, samples were stored and transported inverted. Stable isotope $\left(\delta^{2} \mathrm{H}\right.$ and $\left.\delta^{18} \mathrm{O}\right)$ samples were analysed at Flinders University of South Australia isotope analytical laboratory in Adelaide. The standard procedure for analysis of the Deuterium and Oxygen-18 composition of water is that described by PICARRO (2015). The water samples for ${ }^{14} \mathrm{C}$ were collected using $1.25 \mathrm{~L}$ polyethylene terephthalate (PET) bottles. A total of $5.0 \mathrm{~L}$ of groundwater was collected from each well. The sample bottles were sealed and securely capped. Radiocarbon was analysed using radiometric counting and accelerator mass spectrometry at the Rafter Radio Carbon Laboratory, National Isotope Centre, New Zealand (Rafter Radiocarbon Laboratory, 2016).

The downhole geophysical logs were obtained using borehole logging unit of the South Australian Department of Environment, Water and Natural Resources. The unit consists of data processing unit, winch, cable and logging tools installed in a van. Gamma and neutron probes were run simultaneously and 3-arm caliper tool was run separately. The surface unit controls the logging and movement of the probe and displays and stores data. The probe is connected to the surface unit with the cable that conveys the electrical signals (Wonik, 1990).

Nine high resolution EM lines of varying orientation (Figure 1) with station spacing of $25 \mathrm{~m}$ with infill to higher resolution $(12.5 \mathrm{~m})$ were used over areas of surface features such as sinkholes. A Zonge International GDP-32ii receiver equipped with NanoTEM cards were used to acquire all data for this study. Data were sensed using a single turn $5 \times 5 \mathrm{~m}$ wire loop placed at the centre of each transmitter loop. Data were recorded over two channels, with the second gained up to improve late time decay resolution. Decay data were recorded over 31 time windows to approximately 2 milliseconds after transmitter turnoff. Transmitted fields were generated with a Zonge NT-20 geophysical transmitter energizing a single turn $25 \times 25 \mathrm{~m}$ loop. This transmitter provides an output of $3 \mathrm{Amps}$, at 32 Hertz with a turn-off ramp time of $1.5 \mu$ s. Synchronisation was controlled directly using the GDP-32ii receiver. Data were then used to produce 1D inversion model sections of resistivity using Zonge International's STEMINV modelling program (Mann, 2016).

\section{Results and Discussion}

Direct information about the structure of the subsurface geology can be obtained by drilling boreholes. Downhole geophysical logging provides additional in-situ information to supplement the direct geological information. This is particularly useful where borehole intercept cavities but insufficient recovery of core sample (lost-circulation). Downhole geophysical logs provide continuous depth record of formation properties (Wonik, 2007) such as: caliper logs provide information on drillhole diameter, fractures and are essential in interpreting other logs; gamma logs provide a record of natural radioactivity of the rock penetrated by a drillhole and provides information on lithology and stratigraphic correlation by relating to clays and silt content and permeability; neutron log measures neutrons from an isotopic source at one or several detectors after they 
migrate through material in, and adjacent to, the borehole. Log response results primarily from hydrogen content, but it can be related to saturated porosity and moisture content (Keys, 1990).

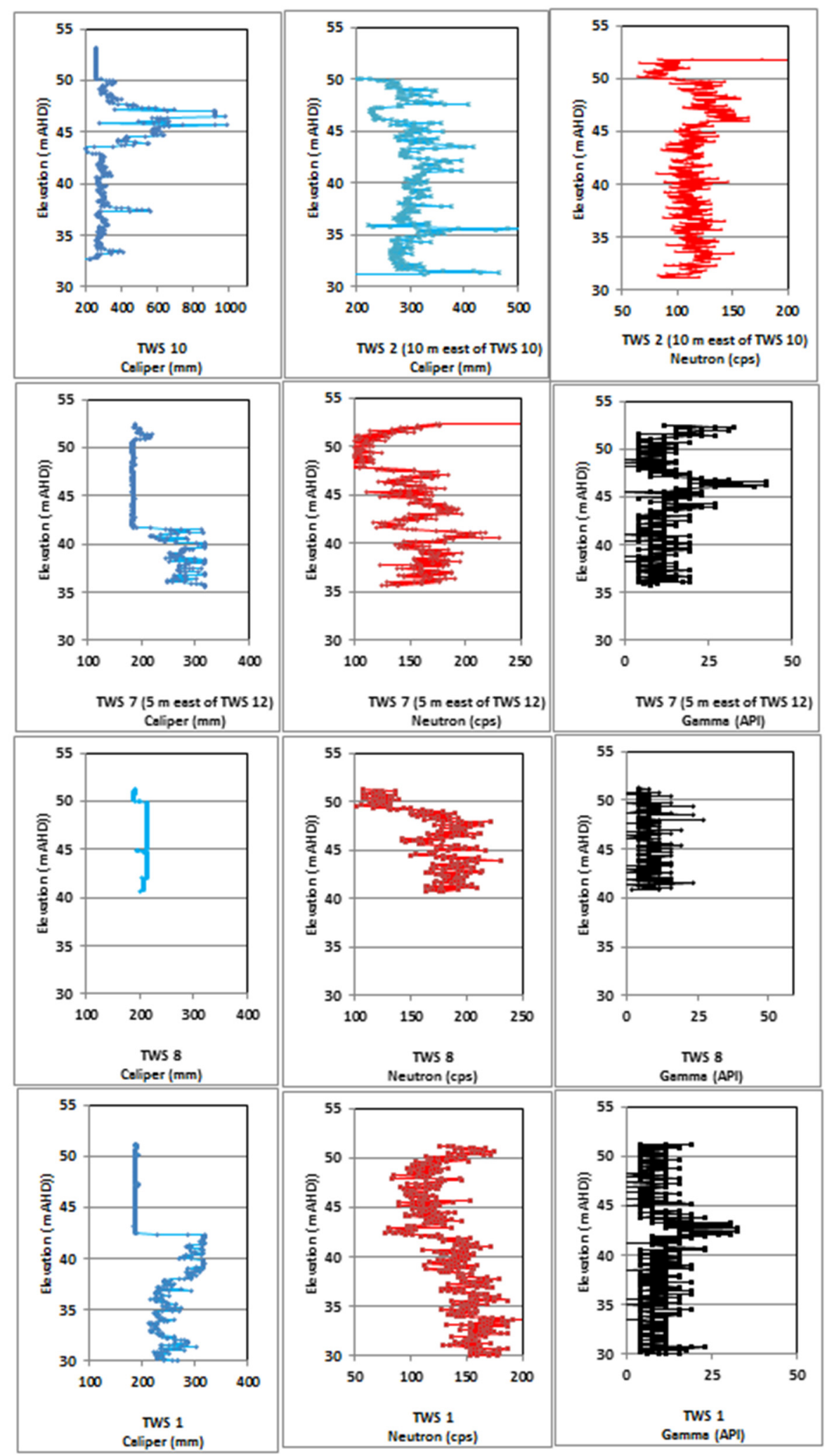

Figure 3. Caliper, gamma and neutron logs for water supply wells 


\subsection{Evidence of Conduit Porosity from Lithological and Downhole Geophysical Logs}

Since geophysical logs have no unique response, logs need to be interpreted with geological information obtained from boreholes. Stratigraphic correlation using caliper, gamma and neutron logs are shown in Figure 3. Bordertown town water supply wells (TWS) $1,2,7,8$ and 10 wells have been logged for depth, gamma, neutron and caliper. Old wells TWS 2 and TWS 7 have been replaced with TWS 10 and TWS 12. As the new well is located within $10 \mathrm{~m}$ from the old well, geophysics for the older wells were used as the replacement well of TWS 12. The six monitoring wells (WRG042-WRG047) along with TWS 10 to TWS 13 were drilled using the rotary drilling method, with resultant loss-circulation occurring in 7 wells. These were encountered; WRG042 at 10-16 $\mathrm{m}$ (58 to $52 \mathrm{mAHD}$ ), WRG043 at 18-23 m (49 to $44 \mathrm{mAHD}$ ), WRG044 at 18-25 m (49 to $42 \mathrm{mAHD}$ ), WRG047 at $10-47 \mathrm{~m}$ (59 to $29 \mathrm{mAHD})$, TWS 10 at $18-25 \mathrm{~m}$ (50.7 to $43.7 \mathrm{mAHD})$, TWS 11 at $19-24 \mathrm{~m}$ (48.3 to 40.3 mAHD), TWS 12 at $21-26 \mathrm{~m}$ (46.3 to $41.3 \mathrm{mAHD}$ ), TWS 13 at $12-18 \mathrm{~m}$ (54.5 to $48.5 \mathrm{mAHD}$ ) depths (Figure 4). In TWS 10, the caliper log indicated full arm extension between $21 \mathrm{~m}$ to $24 \mathrm{~m}$ (47 to $44 \mathrm{mAHD}$ ). The results indicate that loss-circulation (open cavities) occur at the Bridgewater Formation and the upper part of the Murray Group Limestone Formation.
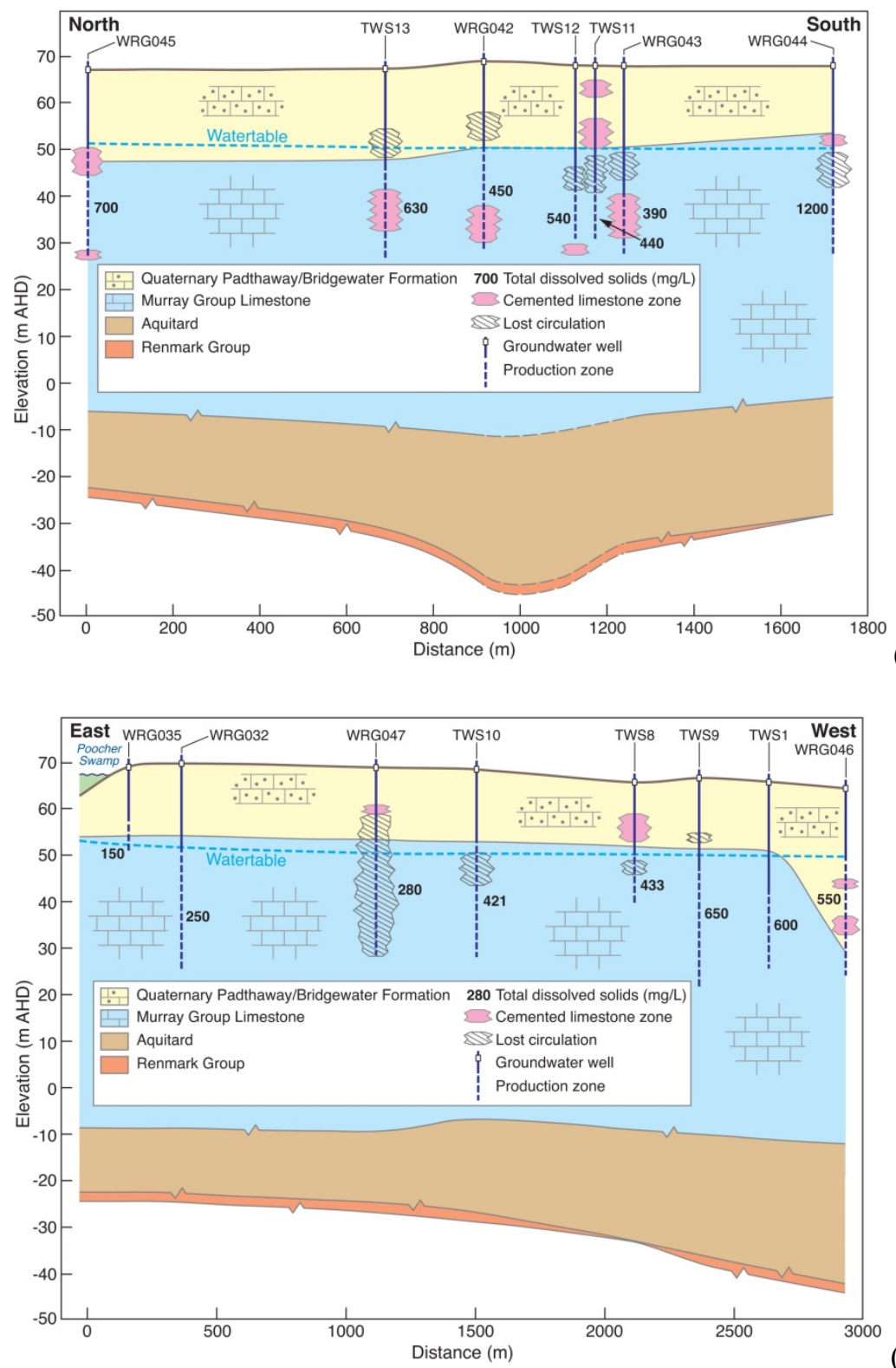

Figure 4. Geological cross sections across the study area (a) north-south (b) east-west 
The older wells TWS 1, TWS 2, TWS 7 and TWS 8 have been drilled using cable tool method and therefore there are no records of cavity development. Gamma log of TWS 1 show at 43 mAHD, higher counts up to 33 API (American Petroleum Institute) indicating a possible clay rich zone. Lithological description at this depth of the TWS 1 is 'white limestone with yellow clay'. Immediately below this, 24-29 m (42 to $37 \mathrm{mAHD}$ ) depth interval lithology is described as 'limestone with yellow, sandy clay and gravel layer', stretching caliper arm to $317 \mathrm{~mm}$. Below $41 \mathrm{mAHD}$, neutron reading slightly increased indicating higher porosity zone of the profile. Higher counts of neutron logs of TWS 1, below 40 mAHD indicate more open limestone. There can be a mismatch between lithological logs when directly compared to downhole geophysical logs. This is because lithological samples are collected at certain depth interval (in this case $3 \mathrm{~m}$ interval) and hence represent 'average of the samples collected' within the depth interval. Therefore, combining geophysical logs with lithological logs is more useful for interpretation than relying on one set of logs. Similarities are observed between caliper log of TWS 10 and neutron log of TWS 2 .

The caliper log of TWS 2 shows presence of cavity or wash-out zones at different depths in the profile. It is apparent that TWS 10 has intercepted a major cavity than that present in TWS 2, even though two sites are about $10 \mathrm{~m}$ apart, indicating complexity of tracking conduits pathways using boreholes. The old well TWS 7 was replaced by TWS 12, and the neutron log of TWS 7 indicates high porosity zone at $41 \mathrm{mAHD}$ (softer limestone with shelly and slightly marly) but $2 \mathrm{~m}$ above this at 43 mAHD gamma counts increased to 42 API indicating a clay or shale rich zone (marl with limestone). Geophysical logs of TWS 8 well shows more or less uniform gamma and caliper logs throughout the profile indicating homogeneous nature of limestone at this location.

\subsection{Evidence from EM Survey}

EM data were examined before being averaged to create a single record; for each channel, for each soundings using TEMAVGW (MacInnes, 2010) software (Mann, 2016). Channels that were considered of poor quality were skipped before averaging each station data. Ungained and gained data were merged to optimize early and late data to create a single sounding for each station. Data were then used to produce 1D inversion models of resistivity using STEMINV (MacInnes and Raymond, 2001) modelling program. Topographic information was used in modelling so sections are presented relative to SRTM (2000) elevations, comparable to m AHD (Mann, 2016).
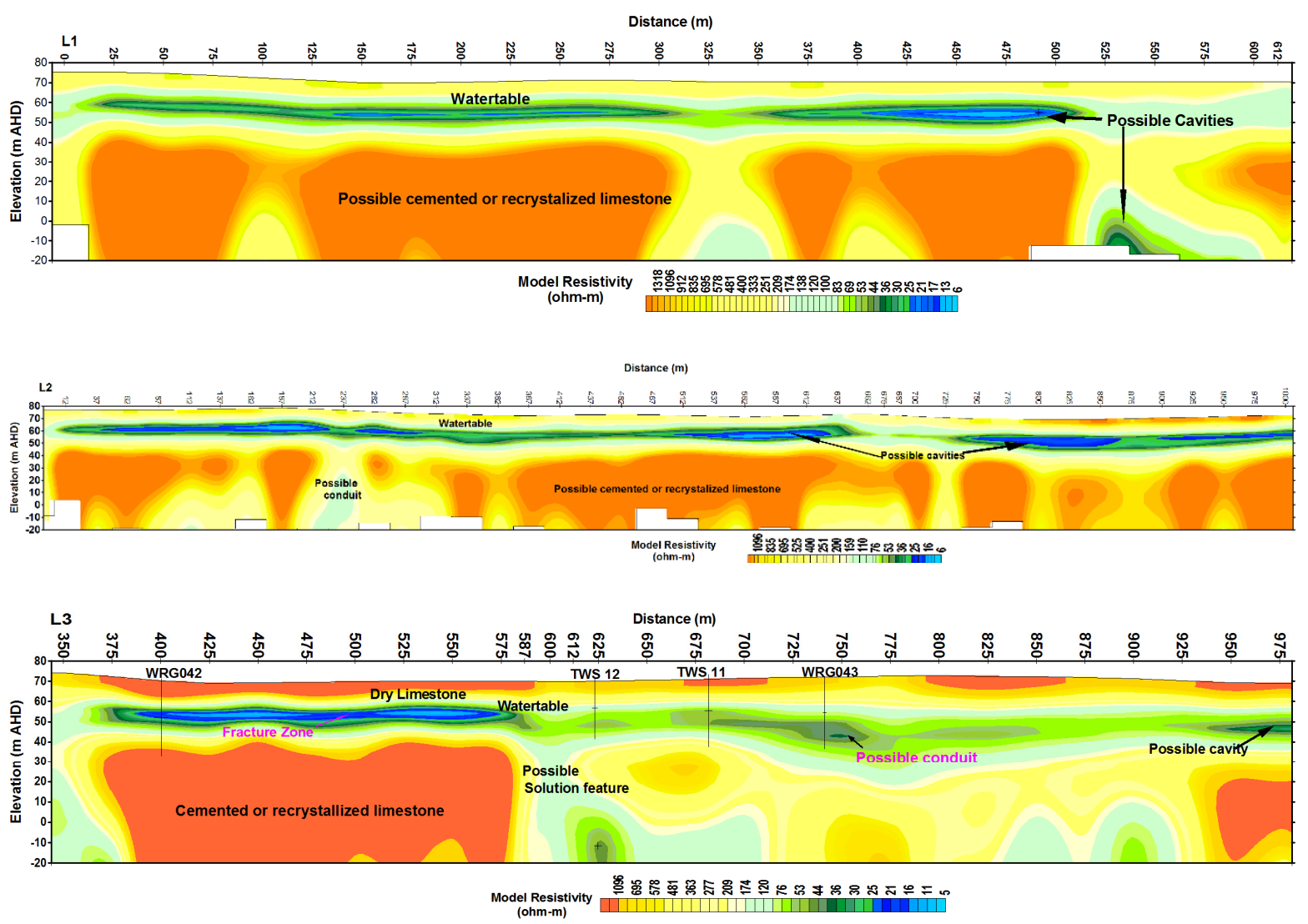

Figure 5. Inverted resistivity sections along lines 1 to 3 (L1 to L3) 
The variation in resistivity of particular minerals can be enormous, for example limestone: $50-10^{7} \Omega \mathrm{m}$; Marls 3-70 $\Omega \mathrm{m}$; Clays: 1-100 $\Omega \mathrm{m}$ (Telford et al., 1990). Other factors such as dissolved minerals in groundwater, fracture zone filled with air or water, consolidation of geologic materials influence the local changes to resistivity. In most cases, a small change in the percentage of water affects the resistivity (Telford et al., 1990). The resistivity of fresh water is about 10-100 $\Omega \mathrm{m}$ (Palacky, 1987), overlapping of resistivity values in the saturated zone requires known features for interpretation of TEM sections. In the shallow substructures, presence of water controls much of the resistivity variations. Measurement of resistivity in general, is a measure of water saturation and connectivity of pore spaces (Cardimona, 2002). Therefore, increasing number of fractures or porosity tends to decrease the resistivity (Cardimona, 2002).
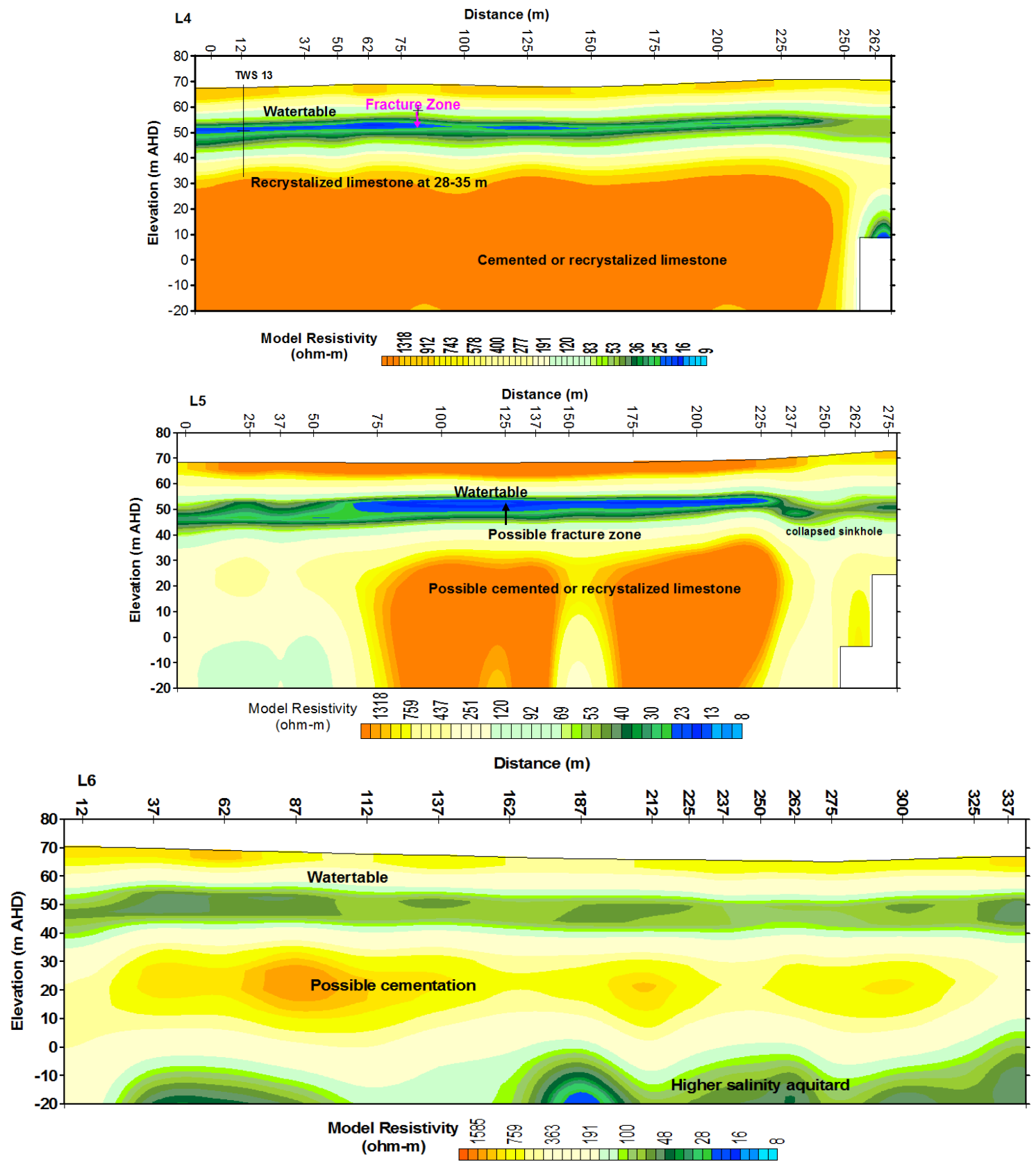

Figure 6. Inverted resistivity sections along lines 4 to 6 (L4 to L6) 
Figure 5 shows the inverted resistivity sections for survey lines L1 to L3. Four distinct resistivity contrast areas are found. The upper high resistivity zones up to $15 \mathrm{~m}$ depth represent the unsaturated zone as the dry limestone is a poor electrical conductor. Marked resistivity anomaly begins about $18 \mathrm{~m}$ depth, which represent the watertable. The lowest resistivity zone ( 5 to $25 \Omega \mathrm{m}$ ) from about $20 \mathrm{~m}$ to $30 \mathrm{~m}$ represents the main fracture zones. For interpretation purpose, wells drilled close to the line L3 are projected on to section L3. For example, fracture zones of wells: WRG042 at 10-16 m; TWS 12 at 21-26 m; TWS 11 at 19-27 m; and WRG043 at 18-23 m are within or at close range to the low resistivity zones of TEM section. In addition, pockets of low resistivity zones were identified as possible subsurface conduits or cavities. The higher resistivity $>250 \Omega \mathrm{m}$ is considered as the cemented or recrystallized limestone. As the degree of cementation varies, the resistivity varies accordingly. The wells projected on to line L3 found cemented limestone: WRG042 at 30-38 m; TWS 12 at 38-40 m; TWS 11 at 3-17 m; and WRG043 at 27-36 m depth intervals, and are compatible with higher resistivity. Groundwater flow may be dominated through fracture zone located at 20-30 m below ground level.

Resistivity sections of TEM lines 4 to 6 (L4 to L6) are given in Figure 6. The line L4 begins at TWS 13 where depth to water is found at $16.2 \mathrm{~m}$, the lost circulation zone at $12-18 \mathrm{~m}$ depth and the cemented limestone at $28-35$ $\mathrm{m}$ depth interval. These observations are in good agreement with resistivity data interpretation and are comparable to range of resistivity values described previously. Resistivity contrast in inverted section L6 is minor (Figure 6), indicating the presence of more homogeneous limestone (no dominant fracture zone or cemented limestone). This is similar to the homogeneity found in geophysical logs of TWS 8 well. Hence groundwater flow in this part of the aquifer may be considered as the matrix flow. Presence of deeper aquitard is evidenced in L6 as indicated by low resistivity at about $-10 \mathrm{~m}$ AHD.
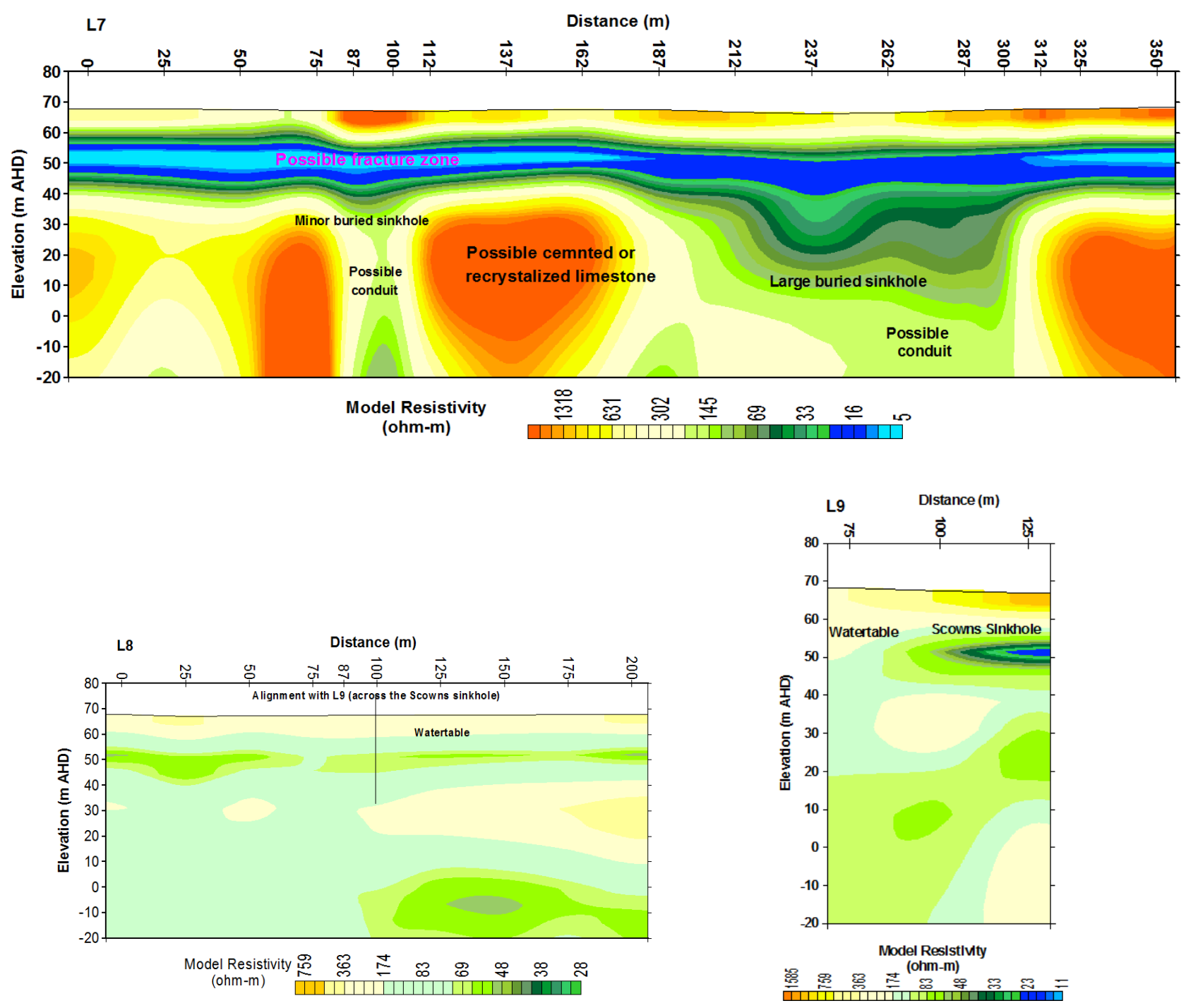

Figure 7. Inverted resistivity sections along lines 7 to 9 (L7 to L9) 
Resistivity sections L7 (Figure 7) runs across two buried sinkholes, as evidenced in circular shaped and minor ground surface depressions at about $87 \mathrm{~m}$ and $237 \mathrm{~m}$ along the line. Resistivity contrasts reappear in this section as lower resistivity, possible fracture zone, occurs at shallow depth of 10 to $20 \mathrm{~m}$ depth (56-46 m AHD), and pockets of high resistivity $(>750 \Omega \mathrm{m}$ ) limestones occurring at below $8 \mathrm{~m}$ depth (at $30 \mathrm{~m}$ AHD), indicating possible layers of cemented limestone. At buried sinkhole locations, near vertical low resistivity portions in the profile may be the possible conduits, could probably be filled with sediment and water. No borehole information is available for this line. Thus, buried or subsidence sinkholes (Waltham et al. 2005) or subsurface cavity locations can be identified based on the characteristics of low resistivity readings. In the saturated zone, when the cavities are filled with fine, loose materials, the electrical resistance is lower as both water and clay are good conductors (Panek et al. 2010). In general, water filled cavities are abundant in karstic limestone aquifers.

The line L8 is about $100 \mathrm{~m}$ upgradient (east) to the Scowns sinkhole and is $200 \mathrm{~m}$ long. The station at $100 \mathrm{~m}$ along L8 (Figure 7) is aligned with the centre of the sinkhole and is intentionally placed to intercept any conduits flow paths that connect to the sinkhole. However, resistivity values indicate presence of homogeneous limestone. This indicates, either conduits connecting the Scowns sinkhole begins at this location or interconnection to existing conduits occur at about $50 \mathrm{~m}$ further south from L8, as occurrence of another sinkhole is found about $100 \mathrm{~m}$ east of L8 (Figure 1). This conjecture was not investigated. The line L9 is positioned across the Scowns sinkhole. The station $125 \mathrm{~m}$ (on L9) is at the centre of the sinkhole. Down to watertable depth, presence of dry soil is indicated by higher resistivity $(>174 \Omega \mathrm{m})$. The low resistivity about $10-25 \Omega \mathrm{m}$, is the water filled gallery of the sinkhole and the conduit system is indicated by low resistivity zones of $25-83 \Omega \mathrm{m}$.

In arid and semi-arid regions, it is common that some of the active sinkholes are capped with a layer of sediment and become dormant during dry summer months. This is evidence in both Poocher Swamp and Scowns sinkholes (Figure 8). With the onset of receiving surface runoff, these sinkholes become active and would act as the sources of point recharge (Figure 9). Somaratne (2015b) reports that during the 1986 flood event, discharge to the Scowns sinkhole was measured at the rate of 500-2000 $\mathrm{m}^{3} \cdot \mathrm{hr}^{-1}$ during $17^{\text {th }}$ to $28^{\text {th }}$ August 1986.

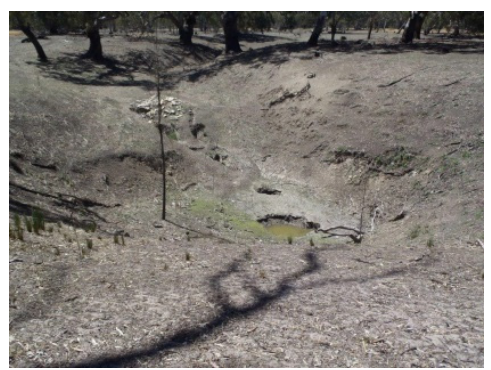

(a)

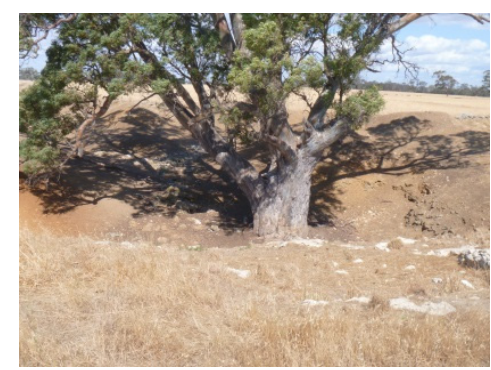

(b)

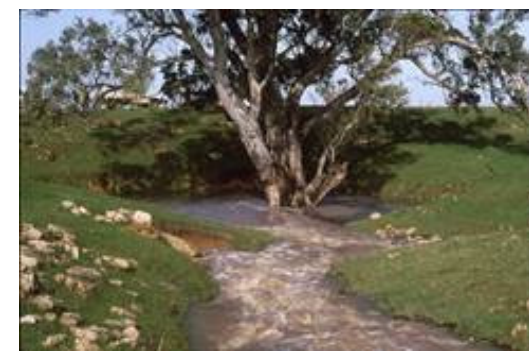

(c)

Figure 8. Sinkhole surface during dry summer (a) Poocher Swamp sinkhole during dry summer covered with sediment (b) Scowns sinkhole during dry summer covered with sediment (c) Scowns sinkhole during August 1986 high rainfall events (Somaratne, 2015b) showing point recharge through the sinkhole

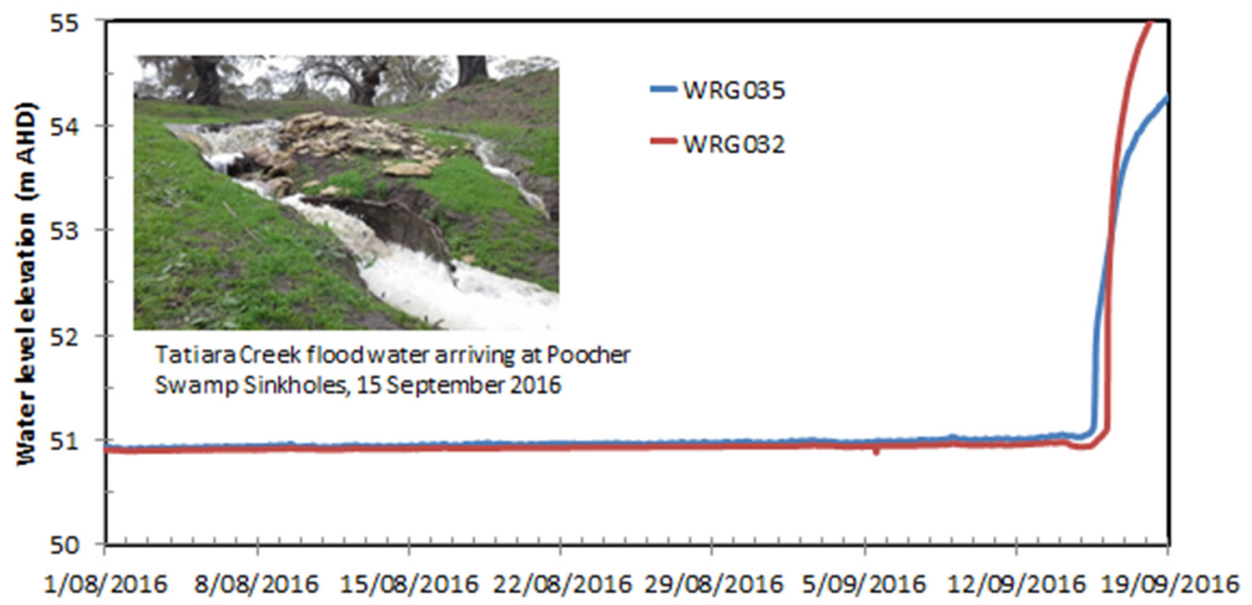

Figure 9. Hydrographs for WRG032 and WRG035 wells in response to recharge event on $15^{\text {th }}$ September 2016 


\subsection{Stable Isotope and Radiocarbon Distribution and Possible Conduit Flow Paths}

Chloride $\left(\mathrm{Cl}^{-}\right)$is a conservative tracer, and in the absence of other sources and sinks, can be used to compare recharge sources with stable isotope $\delta^{18} \mathrm{O}$. The $\mathrm{Cl}^{-}$and $\delta^{18} \mathrm{O}$ data were used to infer the degree of mixing along flow paths from the primary recharge source (Poocher Swamp) to the sampling point. In a karsitic aquifer composition of groundwater chemistry at a sampling point represents a contribution from matrix and conduit flow components. The matrix flow has a longer residence time than the conduit flow. It is therefore possible to compare degree of mixing of matrix and conduit flows relative to two end members, the Poocher Swamp and the pristine limestone aquifer water in WRG044 well (Figure 1) which is located outside the freshwater lens. The degree of mixing between two end members within the freshwater lens is shown in Figure 10 by plotting the values of $\delta^{18} \mathrm{O}$ versus $\mathrm{Cl}^{-}$concentrations. For comparison, available long-term observed rain water $\delta^{18} \mathrm{O}$ and $\mathrm{Cl}^{-}$ from Adelaide is also included. It is noted that Poocher Swamp is about $100 \mathrm{~km}$ inland from the nearest coastline; therefore rain water $\delta^{18} \mathrm{O}$ may be more depleted than the Adelaide (coastal) winter average of $-4.19 \%$ VSMOW. Radiocarbon $\left({ }^{14} \mathrm{C}\right)$ data was used to identify relatively younger water indicated by higher ${ }^{14} \mathrm{C}$ activity in the groundwater mixtures along flow paths. Somaratne et al. (2016) used the relative presence of measured ${ }^{14} \mathrm{C}$ activities, in preference to the corrected ${ }^{14} \mathrm{C}$ or absolute residence time of groundwater recharge to compare residence time between study sites. In this study, correction to measured ${ }^{14} \mathrm{C}$ activity was not made rather comparison between sampled points within the lens was done using measured ${ }^{14} \mathrm{C}$ activity. The $\mathrm{Cl}^{-}, \delta^{18} \mathrm{O}$ and ${ }^{14} \mathrm{C}$ data provide degree of mixing along inferred flow paths. Stable isotope, radiocarbon, $\mathrm{Cl}^{-}, \mathrm{EC}, \mathrm{pH}$ data with well details are presented in Table 1.

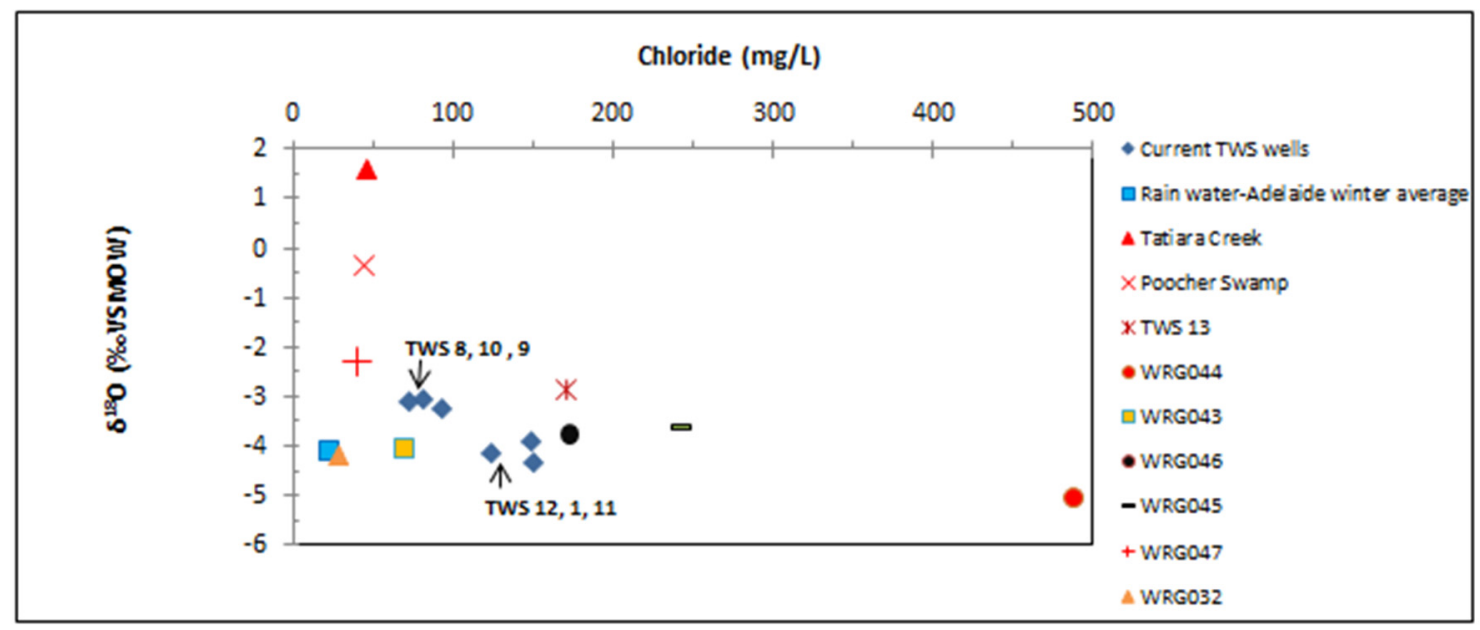

Figure 10. $\delta^{18} \mathrm{O}$ versus $\mathrm{Cl}^{-}$concentrations of groundwater between two end members; Poocher Swamp and WRG044

Both Tatiara Creek and Poocher Swamp water are isotopically enriched relative to regional groundwater (WRG044) and the local rainfall. The enrichment of $\delta^{18} \mathrm{O}(1.58 \%$ ) in the Tatiara Creek indicates creek water has undergone evaporation during sampling period in October 2012, due to relatively high temperature in spring period (Figure 2). The Poocher Swamp receives local surface runoff, and therefore, the enrichment reduced to $-0.34 \%$. The well WRG032 is located $150 \mathrm{~m}$ downgradient to the Poocher Swamp and has $\delta^{18} \mathrm{O}(-4.19 \%)$ and $\mathrm{Cl}^{-}\left(29-35 \mathrm{mg} . \mathrm{L}^{-1}\right)$ indicating the well water is reflective of more recent winter (June-August) recharge received from the Poocher Swamp. The well was sampled in May, 2016. Tatiara Creek and Poocher Swamp are highly dynamic systems, and as such, water chemistry varies significantly over the year, depending on wet-dry cycles. Herczeg et al. (1997) reports annual variation of ${ }^{2} \mathrm{H}$ (10 to $-40 \%$ VSMOW) with variation of chloride concentration in Poocher at about 10-40 mg.L $\mathrm{L}^{-1}$. Thus, wells located closer to the Poocher Swamp (WRG035 and WRG032) tend to mirror water quality of Poocher Swamp. Further downgradient $(1113 \mathrm{~m})$ well, WRG047 recorded lost-circulation throughout the 10-40 m depth interval indicating the presence of large cavity. The $\delta^{18} \mathrm{O}$ $(-2.31 \%)$ and $\mathrm{Cl}^{-}\left(40 \mathrm{mg} . \mathrm{L}^{-1}\right)$ indicate the well has intercepted a major conduit flow path that originates from the Poocher Swamp. The characteristic of regional water quality in the limestone aquifer can be found in the WRG044 well with higher $\mathrm{Cl}^{-1}$ of $487 \mathrm{mg} \cdot \mathrm{L}^{-1}$ and $\delta^{18} \mathrm{O}$ of $-5.06 \%$ indicating older groundwater in Murray Group Limestone. 
Table 1. Source details and radiocarbon and stable isotope data

\begin{tabular}{|c|c|c|c|c|c|c|c|c|c|c|c|c|}
\hline Source & $\begin{array}{l}\text { Depth } \\
(\mathrm{m})\end{array}$ & $\begin{array}{l}\text { Prod. } \\
\text { Interval (m) }\end{array}$ & $\begin{array}{l}\text { SWL } \\
(\mathrm{m})\end{array}$ & $\begin{array}{l}\text { Sample } \\
\text { Depth (m) }\end{array}$ & $\begin{array}{l}\delta^{2} H \\
(\% \text { VSMOW) } \\
\end{array}$ & $\begin{array}{l}\delta^{18} \mathrm{O} \\
(\% \text { VSMOW) } \\
\end{array}$ & $\begin{array}{l}\delta^{13} \mathrm{C} \\
(\% \circ) \\
\end{array}$ & $\begin{array}{l}{ }^{14} \mathrm{C} \\
(\mathrm{pmC})\end{array}$ & $\begin{array}{l}\mathrm{Cl}^{-1} \\
\left(\mathbf{m g} \cdot \mathbf{L}^{-1}\right) \\
\end{array}$ & $\begin{array}{l}\text { EC } \\
\left(\mu \mathrm{S} . \mathrm{cm}^{-1}\right)\end{array}$ & pH & $\begin{array}{l}\text { Temp. } \\
\left({ }^{0} \mathrm{C}\right)\end{array}$ \\
\hline Tatiara & $\mathrm{n} / \mathrm{a}$ & $\mathrm{n} / \mathrm{a}$ & $\mathrm{n} / \mathrm{a}$ & $\mathrm{n} / \mathrm{a}$ & 11 & 1.58 & - & - & 46 & 525 & 8.3 & - \\
\hline \multicolumn{13}{|l|}{ Creek } \\
\hline Poocher & $\mathrm{n} / \mathrm{a}$ & $\mathrm{n} / \mathrm{a}$ & $\mathrm{n} / \mathrm{a}$ & $\mathrm{n} / \mathrm{a}$ & -4.5 & -0.34 & - & - & $27-44$ & 421 & 8.2 & - \\
\hline \multicolumn{13}{|l|}{ Swamp } \\
\hline WRG035 & 18 & $12-18$ & dry & dry & - & - & - & - & 40 & 699 & 7.4 & - \\
\hline WRG032 & 38.7 & $19.3-38.7$ & 19.1 & 21 & -28.2 & -4.19 & -14.3 & 88 & $29-35$ & 612 & 6.7 & 17.1 \\
\hline WRG047 & 40 & $16-40$ & 18.3 & 21 & -14.05 & --2.31 & -14.6 & 74.55 & $35-40$ & 670 & 6.8 & 17 \\
\hline TWS 10 & 40 & $16-40$ & - & pump & -9.4 & -3.05 & $-11,5$ & 45.77 & 81 & 962 & 7.1 & 18 \\
\hline TWS 8 & 26.3 & $16-26.3$ & - & pump & -17.5 & -3.08 & -12 & 61.53 & 73 & 739 & 7.1 & 17.9 \\
\hline TWS 9 & 45 & $20-45$ & - & pump & -18.8 & -3.23 & -11.3 & 60.46 & 93.3 & 1054 & 7.01 & 18 \\
\hline TWS 1 & 40 & $19-40$ & - & pump & -22.4 & -3.89 & -10.6 & 60.29 & 149 & 805 & 7 & 18.1 \\
\hline WRG046 & 40 & $16-40$ & 15.5 & 20 & -23.22 & -3.76 & - & - & 173 & 1326 & 11.6 & 17.8 \\
\hline WRG045 & 40 & $16-40$ & 15.3 & 20 & -22.68 & -3.64 & -12.2 & 60.59 & 242 & 2032 & 6.7 & 18.1 \\
\hline TWS 13 & 40 & $25-40$ & 16.7 & 20 & -17.76 & -2.86 & -12.6 & 53.62 & 171 & 808 & 7.1 & 17.6 \\
\hline WRG042 & 40 & $16-40$ & 17.8 & 21 & -21.64 & -3.49 & -12.5 & 59.95 & - & 888 & 6.9 & 17.4 \\
\hline TWS 12 & 37 & $25-37$ & - & pump & -24.3 & -4.13 & -10.4 & 48.83 & 124 & 907 & 7 & 18 \\
\hline TWS 11 & 37 & $25-37$ & - & pump & -22 & -4.31 & -10.9 & 55.15 & 150 & 805 & 7 & 17.8 \\
\hline WRG043 & 36 & $28.8-36$ & 16.6 & 30 & -23.58 & -4.05 & -12.4 & 67.06 & 70 & 733 & 7.1 & 16.5 \\
\hline WRG044 & 40 & $16-40$ & 16.3 & 20 & -31.29 & -5.06 & -9.7 & 56.49 & 487 & 2849 & 6.8 & 17.3 \\
\hline
\end{tabular}

Note: Tatiara Creek, Poocher Swamp and WRG035 well were dry during May 2016 sampling round. Stable isotope, Cl, EC and pH data were collected in 2012, 2014 and 2016. Prod. Interval = Production zone of the well; SWL=Standing Water Level, EC=Electrical Conductivity.

Gradual depletion of $\delta^{18} \mathrm{O}$ from $-0.34 \%$ at Poocher Swamp to $-2.31 \%$ at WRG047 may be due to minor mixing of conduit flow with ambient groundwater. The highest ${ }^{14} \mathrm{C}$ activity, $88 \mathrm{pmC}$, is at the WRG032 well is the closest location to the point recharge source (Figure 11). The ambient groundwater just outside the freshwater lens, $56.49 \mathrm{pmC}$, is found in WRG044 well confirming the presence of 'older' groundwater. The WRG045 located closer to the boundary records $60.59 \mathrm{pmC}$, presumably due to local recharge. Along the flowpaths, ${ }^{14} \mathrm{C}$ activity decreases due to mixing of recharge water with ambient groundwater: WRG032 (88 pmC), WRG047 $(74.55 \mathrm{pmC})$, TWS $10(45.77 \mathrm{pmC})$. Higher radiocarbon values were observed from TWS 8 to TWS 1 , which may be due to local diffuse recharge; WRG042 (59.95 pmC), TWS 8 (61.53 pmC), TWS 9 (60.46 pmC), TWS 1 $(60.29 \mathrm{pmC})$. The lower radiocarbon values in TWS 10 and TWS 13 indicates the wells may intercept older groundwater from the north-east direction. In WRG045, depleted ${ }^{18} \delta \mathrm{O}\left(-3.64 \%\right.$ ), higher $\mathrm{Cl}^{-1}\left(242 \mathrm{mg} \cdot \mathrm{L}^{-1}\right)$ and relatively younger water $(60.59 \mathrm{pmC})$ can be interpreted as the well received recent vertical recharge that has undergone evaporation. Observed lack of significant variation of $\delta^{18} \mathrm{O}_{\text {as }} \mathrm{Cl}^{-1}$ concentration increases in wells WRG043, TWS 12 and TWS 11 can be interpreted as mixing of inflow from the Poocher Swamp with some vertical recharge received in this part of the aquifer. The $\delta^{18} \mathrm{O}$ values in these wells are comparable to that of Adelaide rain water, enrichment is minor. Lost-circulation zones (Figure 4a) and TEM tomography section (Figure 5-L3) show possible cavity zones in WRG043, TWS 12 and TWS 11, but $\delta^{18} \mathrm{O}$ values are more depleted than TWS 8 to TWS 10 (Table 1). However, ${ }^{14} \mathrm{C}$ data indicates older water in TWS 11 (55 pmC), TWS 12 (48 $\mathrm{pmC})$ and younger water in WRG043 $(67 \mathrm{pmC})$ suggesting that only WRG043 well has a direct link to the Poocher Swamp. 


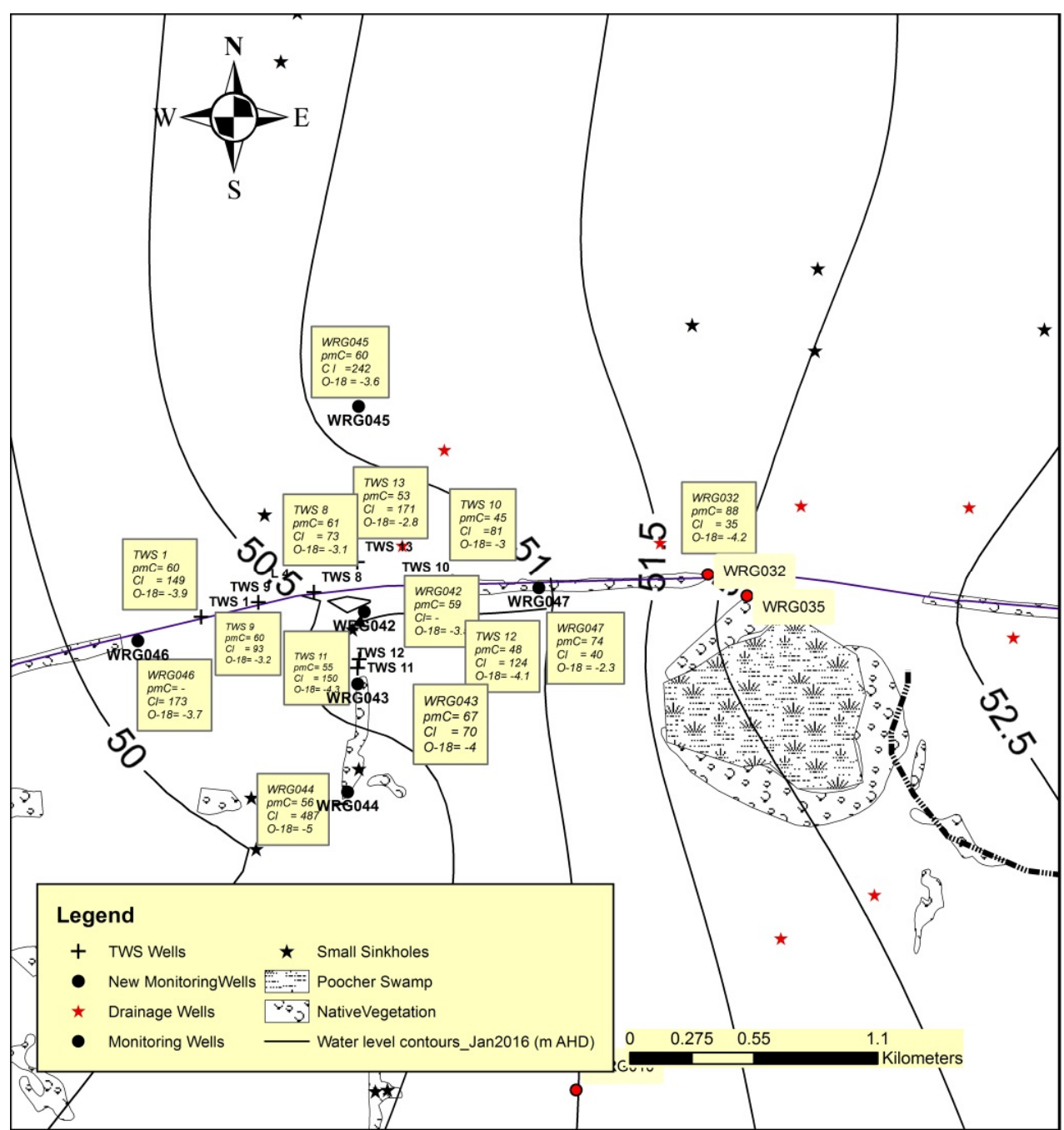

Figure 11. Radiocarbon and stable isotope distribution with inferred flow paths

\section{Conclusion}

Inherent difficulties arise when attempting to trace conduit flowpaths using a single technique given limitations in the each and the large variation in scale of influencing structures. Well drilling is effective but unlikely to intercept discrete structures; geophysical methods are commonly used to compliment well drilling however interpretation of responses from both geologic and hydrologic sequences can be complex; tracer techniques are widely used but defining flowpaths become problematic due to dilution and mixing. We used geological, geophysical, stable isotope and radiocarbon data for assessing the conduit flow paths in the Poocher Swamp freshwater lens. The drillhole data was used to validate and interpret the geophysical results. Low resistivity zones of the TEM tomography sections had excellent correlation to fracture zones identified during well drilling, and dowhnhole geophysical logs. In the saturated zone, conduits may be filled with both water and clay and therefore, is difficult to identify by resistivity survey alone as both water and clay are low resistivity materials. Therefore use of stable isotopes and radiocarbon is a useful tool in identifying preferential groundwater flow paths. Wide range $\left(-0.34 \%\right.$ o at Poocher Swamp to $-5.06 \%$ at WRG044) of ${ }^{18} \mathrm{O}$ and ${ }^{14} \mathrm{C}$ activity (88 pmC at WRG032 to $56.49 \mathrm{pmC}$ at WRG044) indicate spatial inhomogeneity of isotopes and groundwater age. The presence of relatively enriched ${ }^{18} \mathrm{O}$ signatures and higher radiocarbon activity is an indication of presence of conduit flows that carry recharged water from the Poocher Swamp.

\section{Acknowledgments}

This study was funded by the South Australian Water Corporation under resource assessment of the Poocher Swamp freshwater lens. Authors thank Nardine Habner for arranging water sampling and laboratory analyses in 2016, and Jeff Lawson for providing lithological and downhole geophysical data. 


\section{References}

AS/NZ 5667.5. (1998). Water Quality Sampling-Guidance on the Design of Sampling Programs, Sampling Techniques and the Preservation and Handling of Samples; AS/NZS 5667.5; Australia/New Zealand Standard: Homebush, Australia.

Cardimona, S. (2002). Electrical resistivity techniques for subsurface investigation. Department of Geology and Geophysics, University of Missouri-Rolla, Rolla, USA. Retrieved April 21, 2016 from https://www.researchgate.net/publication/242692638_ELECTRICAL_RESISTIVITY_TECHNIQUES_FO R_SUBSURFACE_INVESTIGATION

Edwards, A. E., Amatiya, D. M., Williams, T. M., Hitchcock, D. R., \& James, A. L. (2013). Flow characterization in the Santee Cave system in the Chapel Branch Creek watershed, upper coastal plain of South Carolina, USA. Journal of Cave and Karst Studies, 75(2), 136-145. http://dx.doi.org/10.431/ 2011ES0262.

Einsiedl, F. (2005). Flow system dynamics and water storage of a fissured porous karst aquifer characterized by artificial and environmental tracers. Journal of Hydrology, 312(1-4), 312-321. http://dx.doi.org/10.1016/ j.jhydrol.2005.03.031.

Farooq, M., Park, S., Song, Y.S., Kim, J.H., Tariq, M., \& Abraham, A. A. (2012). Subsurface cavity detection in a karst environment using electrical resistivity (er): a case study from yongweol-ri, South Korea. Earth Sci. Res. SJ., 16(1), 75-82.

Herczeg, A. L., Leaney, F. W. J., Stadter, M. F., Allan, G. L., \& Fifeld, L. K. (1997). Chemical and isotope indicators of point source recharge to karst aquifers, South Australia. J. Hydrol., 192, 271-299.

Keys, W. S. (1990) Borehole geophysics applied to groundwater investigations, Chapter E2, Techniques of water resources investigations of the United States Geological Survey, U.S. Geological Survey, Denver, USA.

Knierim, K. J., Pollock, E. D., Hays, P. D., \& Khojasteh, J. (2015). Using stable isotopes of carbon to investigate the seasonal variation of carbon transfer in a northwestern Arkansas cave. Journal of Cave and Karst Studies, 77(1), 12-27. http://dx.doi.org/10.4311/2011ES0264

MacInnes, S. (2010). TEMAVGW Documentation v1.10 Documentation Zonge Engineering and Research Organization, Inc., Tucson, USA.

MacInnes, S., \& Raymond, M. (2001). STEMINV: Smooth-Model TEM Inversion, ZONGE Data Processing, Version 3.0, Zonge Engineering and Research Organization, Inc., Tucson, USA.

Mann, S. (2016). NanoTEM Electro Magnetic Survey, Logistic Summary. Zonge Enginnering and research Organization (Australia) Pty Ltd, Report no: 150265, 39 Raglan Avenue, Edwardstown, SA 5039, Australia.

Martinez-Lopez, J., Rey, J., Duenas, J., Hidalgo, C., \& Benavente, J. (2013). Electrical tomography applied to the detection of subsurface cavities. Journal of Caves and Karst Studies, 75(1), 28-37. http://dx.doi.org/ $10.4311 / 2011 \mathrm{ES} 0242$.

Metwaly, M., \& AlFouzan, F. (2013). Application of 2-D geoelectrical resistivity tomography for subsurface cavity detection in the eastern part of Saudi Arabia. Geoscience Frontiers, 4(2013), 469-476.

Nativ, R., Gunay, G., Hotzl, H., Reichert, B., Solomon, D. K., \& Tezcan, L. (1999). Separation of groundwater flow components in a karstified aquifer using environmental tracers. Applied Geochemistry, 14(8), 1001-1014. http://dx.doi.org/10.1016/so883-2927(99)00012-8

Palacky, G. V. (1987). Resistivity characteristics of geologic targets. In Nabighian, M.N (ed.), Electromagnetics Methods in Applied Geophysics Theory: Tulsa, Okla.. Society of Exploration Geophysicists, 1, 53-129.

Panek, T., Margielewski., Taborik, P., Urban, J., Hradecky, J., \& Szura, C. (2010). Gravitationally induced caves and other discontinuities detected by 2D electrical resistivity tomography: case studies from the Polish Flysch Carpathians. Geomorphology, 123, 165-180.

PICARRO. (2015). PICARRO L2130-i $\delta \mathrm{D}$ and $\delta^{18} \mathrm{O}$ High Precision Isotopic Water Analyser, PICARRO Inc, Santa Clara, USA. Retrieved April 28, 2016, from http://www.picarro.com/products_solutions/ peripherals/for_h2o/ih2o_solids_liquids_and_vapor 
Plummer, L. N., Busenberg, E., McConnell, J. B., Drenkard, S., Schlosser, P., \& Michel, R. L. (1998a). Flow of river water into a karstic limestone aquifer-1. Tracing the young fraction in groundwater mixtures in the Upper Floridan aquifer near Valdosta, Georgia. Applied Geochemistry, 13(8), 995-1015.

Rafter Radiocarbon Laboratory. (2016). GNS Science, National Isotope Centre, New Zealand. Retrieved April 28, 2016, from http://www.gns.cri.nz/Home/Services/Laboratories-Facilities/Rafter-Radiocarbon-Laboratory

Somaratne, N. (2014). Characteristics of point recharge in karst aquifers. Water, 2014(6), 2782-2807. http://dx.doi.org/10.3390/w6092782.

Somaratne, N. (2015a). Karst aquifer recharge: A case history of over simplication from the Uley South Basin, South Australia. Water, 2015(7), 464-479. http://dx.doi.org/10.3390/w7020464

Somaratne, N. (2015b). Pitfalls in application of the conventional chloride mass balance (CMB) in karst aquifers and use of the generalized CMB method. Environ. Earth Sci. http://dx.doi.org/10.1007/s12665-015-4038-y

Somaratne, N., Mustafa, S., \& Lawson, J. (2016). Use of hydrochemistry, stable isotope, radiocarbon, ${ }^{222} \mathrm{Rn}$ and terrigenic ${ }^{4} \mathrm{He}$ to study the geochemical processes and the mode of vertical leakage to the Gambier Basin Tertiary confined sand aquifer, South Australia. Water, 2016(8), 180. http://dx.doi.org/10.390/w8050180

SRTM. (2000). Shuttle Radar Topography Mission. The National Space Administration (NASA) and the National Geospatial Intelligence Agency (NGA). U.S. Geological Survey, USA. Retrieved February 2, 2016, from https://ita.cr.usgs.gov/SRTM

Telford, W. M., Geldart, L. P., \& Sheriff, R. E. (1990). Applied Geophysics (2nd Ed.). Cambridge University Press.

Tweed, S. O., Weaver, T. R., \& Cartwright, I. (2005). Distinguishing groundwater flow paths in different fractured rock aquifers using groundwater chemistry: Dandenong Ranges, southeast Australia. Hydrogeology Journal, 13(5), 771-786.

Vail, J. (2011). Groundwater Sampling; SESDRPROC-301-R3; U.S. Environmental Protection Agency, Science and Ecosystem Support Division: Athens, GA, USA.

Waltham, T., Bell, F. D., \& Culshaw, F. D. (2005). Sinkholes and Subsidence: Karst and Cavernous Rocks in Engineering and Construction. Springer-Verlag, Chichester, UK.

Wonik, T. (2007). Borehole logging. In K. Knodel, G. Lange, \& H. J. Voigt (Eds.), Environmental Geology: Handbook of Field Methods and Case Studies (pp. 431-474). Springer Press, Berlin.

WWRD. (2015). Water for a sustainable world, The United nations World water Development Report 2015. UNESCO, Paris, France.

Zhu, J., Currens, J. C., \& Dinger, J. S. (2011). Challenges of using electrical resistivity method to locate karst conduits-A field case in the Inner Bluegrass Region, Kentucky. Journal of Applied Geophysics, 75, 523-530.

\section{Copyrights}

Copyright for this article is retained by the author(s), with first publication rights granted to the journal.

This is an open-access article distributed under the terms and conditions of the Creative Commons Attribution license (http://creativecommons.org/licenses/by/4.0/). 